\title{
TURKEY-US RELATIONS IN AN AGE OF REGIONAL AND GLOBAL TURMOIL: CHALLENGES AND PROSPECTS
}

\section{EDITORIAL INTRODUCTION}

\section{Ziya Öniş and Şuhnaz Yılmaz}

This special issue on Turkish-American relations with a specific focus on the Middle East aims to analyze a complex web of relations at a critical regional and global juncture, with important implications well beyond bilateral relations. The idea for this special issue emerged during the "Turkish-American Alliance in a Volatile Region: Challenges and Opportunities" Conference organized by the Center for Globalization and Democratic Governance (GLODEM) at Koç University, İstanbul, on March 29, 2012. The insightful and well-rounded nature of the presentations and the extensive interest they received from the academic community compelled us to examine several important points and intriguing questions which were raised during the conference in a much more comprehensive and systematic manner.

The articles in this special issue highlight the complexities of the Turkish-American partnership in an age of acute global and regional turmoil. The future of the Arab Revolutions is surrounded by a great deal of uncertainty. Progress towards a political opening in the Arab world is not likely to be a smooth, uni-linear process. We may expect significant crises and reversals on the way, as the events in Libya, Egypt and Syria clearly testify. Similarly, the Western world has still not emerged from deep financial and economic crises, which clearly limit their ability to make a positive impact on the transformation of the Middle East on a scale comparable to the transformations that occurred in the post-Soviet Central and Eastern Europe some twenty years ago. Moreover, the increasing importance of new and powerful 
actors, such as China and Russia, as a part of shifting patterns of globalization accelerated by the global economic crisis of 2008 and beyond, generate new fault lines and uncertainties in an already complicated picture. Within this broad global and regional context, we aim to draw attention to the changing dynamics of Turkish foreign policy and Turkish-American partnership, which are currently very significant and will continue to require further scholarly attention in the future.

The articles have been selected and organized in a tightly interwoven and complementary manner. In the first paper entitled "New Directions in Turkey-U.S. Relations," Sabri Sayari focuses on the main reasons for the frequent shifts and volatility in the bilateral relationship during the past decade. The main argument of the article is that the evolution of the relationship between Turkey and the US has been influenced by three main developments: regional security problems in the Middle East; the relative decline of US power on the global scene and the systemic trend toward multi-polarity; and the emergence of new trends in the Turkish foreign policy shaped by the Justice and Development Party (AKP) government since 2002 .

Moving from the systemic to the regional level, Sayari highlights five critical developments that have had a decisive influence on the ups and downs of bilateral relationsnamely, the war in Iraq, the Kurdish problem as well as Turkey's fight against PKK terrorism, Iran's quest to develop its nuclear capability, the deterioration of Israeli-Turkish relations, and the implications of the Arab Spring. The article concludes by identifying the bilateral relationship as a "loose interdependence," which refers to deepening military and political ties and cooperation on some issues and to increasing tensions related to others. In this article, Sayari provides an outstanding general framework, which succinctly analyzes all recent events on the bilateral agenda related to the region. Thus, he offers a compelling illustration of the underlying currents of this volatile relationship. 
In the second article, Nur Bilge Criss offers a historical context for a better understanding of current relations. This article analyzes the US-Turkey and Middle East triangle with reference to the Cold War period and the contemporary spillover effects of the Cold War. The author argues that the recent developments taking place in the Middle East region could lead to the emergence of a new Cold War. The article points to the persisting divisions between Arabs and Turks and presents a very critical view of AKP's "new" diplomacy as counterproductive. Criss concludes that, as a result of these policies and changing regional dynamics, Turkey's foreign relations have currently taken a problematic turn not only with its neighbors, but also with its western allies.

The following two articles, by Meliha Altunışık and Lenore Martin, present a thematically complementary pair. Their primary focus is on how changing regional dynamics in the Middle East affect bilateral relations. By focusing on different time periods, before and after the Cold War, Meliha Altunışık offers a clear account of the fluctuations in these bilateral relations. Altunışık argues that international, regional and domestic changes converged or diverged the two countries' interests and policies in the Middle East region. These developments consequently gave way to a readjustment of Turkey's significance in the eyes of US policy-makers as well. The article concludes that, despite reoccurring tensions, because of shared interests, the alliance has been preserved due to several bargaining processes. Yet, the author also highlights that since Turkey develops its own particular interests concerning the Middle East, the bargaining becomes more challenging for both sides. In "Turkey and the US in a Bipolarizing Middle East" Lenore Martin underlines that the systemic structure of the Middle East is changing. Martin argues that the multipolar system in the Middle East is becoming increasingly bipolar, with Iran and the United States constituting the two poles. Due to common challenges and threats, this bipolarization requires Turkey and the US to cooperate more closely in their Middle East policies. The author starts with an 
analysis of the multipolar Middle East after the Cold War period and Turkey's balancing role in the region, and then continues with the major events leading to the beginning of bipolarization. The author argues that the multipolar system of the Middle East between the years 1990 and 2010 offered Turkey the opportunity to increase its soft power in the region through trade, cultural and diplomatic ties. This systemic structure also enabled Turkey to play a "balancing role" in the region, through friendly relations with Iran and Syria.

Lenore Martin argues that the origins of bipolarization started in 2011, through a series of events giving Iran a chance to "expand its power and influence in the region." These events are the Arab Uprisings, the withdrawal of US forces from Iraq, and Iran's progress and potential for the development of nuclear weapons. In this new conjuncture, the article points out that, from the US perspective, Iran's increasing influence is a challenge, while from the Iranian perspective US and Israeli threats to its security are the real danger. The author also highlights the effect of "strong leaders" on the processes of alliance and policy formation. In the sections where the article focuses on the implications of the Syrian Uprising for bipolarization and on the impact of this bipolarization for the Middle East, the author enriches her argument by reflecting not only a range of issues such as leadership, national security and energy, but also highlights the interests of different international actors in the region. The author argues that the bipolarizing system in the Middle East and increasing threats to Turkish and US national interests require a higher level of policy coordination and alignment. However, she also argues that for this alignment "Turkey's alienation from Israel" is one of the most significant obstacles.

The following article entitled “Arab Uprisings and Completing Turkey’s Regional Integration: Challenges and Opportunities for US-Turkish Relations” by Kemal Kirişçi addresses one of the weakest links and an often neglected aspect of the relations: the economic dimension. This paper analyzes whether the Arab Uprisings could create a new 
opportunity for a regional economic integration and what would the challenges and opportunities be for Turkey and the US. The article consists of three main sections, focusing on (1) Turkey's economic engagement with its neighbors; (2) the relationship between peace, stability and regional integration; and (3) the challenges for Turkey concerning an economic integration with the region in the future. The article offers a novel perspective based on economy, focusing more specifically on the "trading state" character of Turkey and highlighting that trade has been a significant factor in the country's integration with its neighborhood.

The article points out that the Arab Uprisings have a mixed effect on Turkey's economic integration with the region. In his analysis, Kirişçi focuses on Turkey’s economic integration with its neighborhood by indicating three major engagement items: Turkish FDI stocks in neighboring countries, the movement of people into Turkey, and the transfer of remittances from Turkey emerging due to Turkey being an attractive country for migrant workers from the Black Sea area and the Middle East. According to the author, developments in Syria present the greatest challenge for Turkey's future economic integration with the Arab World. The author argues that, although achieving a regionalization similar to that of Europe is not likely, it is still worth trying for Turkey, the EU and the US to create at least a platform of dialogue. Kirisci concludes that, in the long term, Turkey could find greater opportunities for deeper economic integration with the Arab world, but only if the related countries are also willing to support economic regionalization and are encouraged to develop a political agenda promoting regional economic integration.

The final two articles of the special issue focus more specifically on the security dimension, which has been one of the main pillars of the bilateral relations from the outset. Tarık Oğuzlu aims to address the challenging question of "How has the decade-long Turkish American strategic relationship through NATO evolved in the post-Cold War era?" To this 
end, he examines first Turkey's and the United States' approaches toward NATO, by making a distinction between identity-related and security-related considerations. Then, the author focuses on the convergent and divergent positions of Turkey and the US regarding the issues on NATO's agenda. With regards to these issues, the article examines three main topics: (1) enlargement, resulting from arealization and NATO's globalization; (2) the Missile Defense Shield Initiative; and (3) NATO's involvement in the MENA region. The author concludes that, although there are diverging perspectives on some of the issues on the agenda, the commitment and strategic cooperation within the context of NATO will continue because of national security considerations.

Mustafa Kibaroğlu zooms in on a rather controversial hot issue, namely the Missile Defense Shield Initiative, a very critical development raised in the previous article as well. This article examines the different aspects of the development and expansion of the US' Missile Defense Project: technological characteristics, reactions from other countries, the deliberation of the US and Turkey for the deployment of the systems on Turkish territory, and the evaluation of Turkey's geostrategic place regarding the project within the NATO framework. Concerning the reactions to the project, the article refers to the positions of Russia, China, the European allies, and Turkey. As for Turkey, the development of its air defense capability is considered a positive step. However, the author argues that the practical use of the project is limited for Turkey, since the threat posed by short- and medium-range ballistic missile capabilities is more relevant for its security. Moreover, Turkey is also concerned that Russia and China could stop cooperation in the area of disarmament and arms control.

Once the US moved towards cooperation in developing the missile defense project in the context of the NATO alliance, the disagreements between the US and its European allies were resolved. The US preferred to sign bilateral treaties with Poland and the Czech Republic 
for the deployment of radar systems in 2008. With the argument that Iran's capabilities were not enough to launch an attack on US territory, in 2009 the Obama administration called off the plans for deployment in Eastern Europe, yet maintained the view that the deployment of major components of the project is still necessary for allied territories closer to Iran. This change of strategy according to the author increased the significance of Turkey for US authorities. Since the first Iraq War in 1991, Turkey has been willing to deploy air defense system on its territory, especially in regions close to the Middle East. The article argues that the Turkish government still has three main concerns: Ankara preferred the project to be not only a US initiative, but rather a NATO one (this was based on past experiences about the Jupiter missile crisis); the Turkish authorities doubted that the US' main concern was the security of Israel against a threat posed by Iran, and not Turkish security per se; and the Turkish government did not want any country against which the project is developed to be named. This strategy has two main motivations: not to deteriorate relations with neighboring Iran, and to prevent Iran from exploiting this situation to justify further advancement of its capacities. The radar site at Kürecik, Malatya, started to operate concomitantly with NATO's Chicago Summit in May 2012. The author concludes that, despite some concerns, Turkey would enhance it security perception with the presence of these new NATO defense assets on its territory.

The detailed investigations of Turkish-American relations in the articles included in the present special issue naturally leads us to some of the more general concerns associated with Turkish foreign policy during the later phase of the AKP era. One of the problems with the " new" and more assertive and independent style of Turkish foreign policy associated with the Davutoğlu era of recent years has been the absence of a firm Western and European 
anchor. ${ }^{1}$ Although Turkish-American relations have improved during the Obama era, the relationship with the EU constitutes the weak link in the Turkey-USA-EU triangle. The improvement of relations with the US could be interpreted as a pragmatic-security-based approach, rather than a strong re-affirmation of Turkey's Western identity. Western perceptions of Turkey are increasingly that of an active and more independent regional player in the Middle East, whose Muslim identity has emerged as its dominant identity nexus during the AKP era. This position is, indeed, in striking contrast to the single-minded western orientation of the secular elites in the previous era. ${ }^{2}$ Thus, the pendulum has swung from one end to the other.

A major challenge for Turkish foreign policy in the coming years is the problem of reconstituting the Turkey-USA-EU triangle. Revitalizing Turkey's Europeanization process is particularly crucial in this context. In retrospect, the EU membership process was crucial not only in terms of its economic benefits, but also in terms of its positive impact on the domestic democratization process and its ability to practice a balanced foreign policy based on soft power. The Arab Spring provides a structural context for a rejuvenation of Turkey's relations with the EU given that both would benefit from cooperation. Structural openings alone, however, are not sufficient to produce favorable outcomes. Agency also matters a great deal.

\footnotetext{
${ }^{1}$ Ziya Öniş and Şuhnaz Yılmaz, "Between Europeanization and Euro-Asianism: Foreign Policy Activism During the AKP Era," Turkish Studies, Vol.10, No.1, (Spring 2009), pp. 7-24; Ziya Öniş, "Multiple Faces of the 'New' Turkish Foreign Policy: Underlying Dynamics and a Critique". Insight Turkey, Vol. 13, No. 1, (2011), pp. 47-65; Ziya Öniş, "Turkey and the Arab Spring: Between Ethics and Self-Interest," Insight Turkey, Vol. 14, No. 3, (2012), pp. 45-63; Fuat Keyman, "Globalization, Modernity and Democracy: In search of a viable domestic polity for a sustainable Turkish foreign policy," New Perspectives on Turkey, No.40, (Spring 2009), pp. 7-27.
}

\footnotetext{
${ }^{2}$ Ahmet O. Evin, Kemal Kirişci, Ronald H. Linden, Thomas Straubhaar, Nathalie Tocci, Juliette Tolay and Joshua W. Walker, Turkey and Its Neighbors: Foreign Relations in Transition, (Boulder Colo: Lynne Rienner Publishers, 2012); Eduard Soler, "The Conceptual Architecture of Turkish Foreign Policy: An update in light of regional turbulence," Documentos CIDOB, June 2012. ; Zalmay Khalilzad, Ian O. Lesser and F. Stephen Larrabee, The Future of Turkish-Western Relations: Toward a Strategic Plan, (Santa Monica: RAND Publications, 2000).
} 
Yet, there are too few signs in both Turkey and the EU to suggest that there currently exists the leadership and vision necessary to take the bold initiatives required to reactivate the relationship.

In the absence of a firm Western or EU anchor, Turkish foreign policy in recent years has displayed two central weaknesses. The first one of these is the growing trend towards the bilateralization of relationships with key neighbors. This trend poses a problem in relations with a number of countries, notably with Russia, Iran and Syria, in addition to the US. Trying to conduct foreign policy as part of a series of bilateral moves without a firm anchor and a set of priorities is likely to weaken Turkish foreign policy and its potential favorable impact as an important middle power in its region. The second issue of concern is Turkey's over-activism and tendency to act unilaterally, leading to its over-involvement in Middle Eastern conflicts and notably in the domestic conflicts of neighboring states, such as Syria. There clearly exists an expectations-capability gap. Despite its successful moves as a rapidly rising regional power, in a number of instances Turkey has been trying to punch beyond its weight by overextending itself in Syria and the wider Arab world. This may have the additional repercussions or unintended consequences of drawing Turkey into sectarian conflicts, with the Sunni-Shiite divide constituting one of the major deepening fault lines in the Middle East. Turkey may increasingly find itself as the champion of the Sunni cause in the Arab Middle East, although this may not have been the intention of the Turkish foreign policy elite in the first place. Clearly, this has a major destabilizing potential, with Turkey finding itself in a growing confrontation with Iran, whose regional power aspirations clearly coincide with playing a leadership role for the Shiite elements in the Arab world, notably in Iraq and Syria. For future prospects, we are broadly optimistic concerning the resilience of the partnership in a world of intense regional and global uncertainty. Yet, major crises have the potential to upset this equilibrium. Ultimately, it is perhaps Iran and Iraq, and not Syria, who 
will have a crucial bearing on the future of Turkish-American relations. A possible unilateral strike by Israel on Iran supported by the US or a direct US military action against Iran is likely to have devastatingly negative consequences for Turkish-American relations. Both at the elite level and for the public at large, military action against Iran would generate widespread resistance. At the same time, Turkey as a key member of the Western security complex and NATO would find itself in a very difficult situation, if it actively opposed such military action. This possibility suggests that the Turkish-American alliance may be prone to crisis on a much larger scale in the coming years than has hitherto been the case.

Similarly, Iraq presents a case of significant tension in the Turkish-American partnership. Turkey's unilateral engagement with the Kurdish region of Northern Iraq as a means of containing its own domestic Kurdish conflict clearly runs counter American intentions to engage directly with Baghdad and maintain the territorial integrity of Iraq. This is, indeed, a novel and paradoxical development considering that Turkish policy-makers in the past were critical of US intentions relating to Northern Iraq. The US position was often identified as an attempt to form an independent Kurdish state on the borders of Turkey, which, in turn, was conceived as a major security threat for the territorial unity of the Turkish state. In a nutshell, Iran and Iraq are likely to constitute the first and second major areas of tension, followed by Syria in third place. We should recognize, however, that these areas of tension are highly interdependent. For example, growing sectarian violence in Syria will naturally have a negative effect on sectarian divisions in Iraq, further enhancing the pivotal role of Iran in regional conflicts. Moreover, if Turkey is unable to deal effectively with its Kurdish problem, this issue will have wider repercussions for Turkish foreign policy, the future of regional stability, as well as the durability of the Turkish-American alliance, once again pointing to the intricate links between domestic politics and international affairs. 
A number of overarching themes emerge in all of the articles. At a time of global systemic transformations and deepening regional fault lines, ambiguity and volatility emerge as predominant characteristic of a highly complex political terrain. Both global actors, such as the US, and regional actors, such as Turkey, need to deal with the quite unintended and unforeseen consequences of sweeping change. The quest to adapt to these changes and at the same time the desire to shape them gives way to often complementary, yet at times conflicting interests between the two countries. On the one hand, US involvement and interests persist in the Middle East as a global power, despite new areas of primary attention, such as a "pivot to Asia." On the other hand, Turkey attempts to carve a space for maneuvering and to increase its influence as a rising regional power. Despite a certain mismatch between capabilities and perceptions, Turkey has indeed emerged as one of the most significant players in its region. These dynamics indicate an enduring and critical bilateral relationship with co-existing elements of cooperation and contention. Moreover, there is also a strong link between domestic and international factors. The overall perspective of the present volume underlines the resilience and durability of the Turkish-American partnership, in spite of frequent crises and tensions that underpin the relationship in an environment of drastic global and regional change and ambiguity. 